\title{
Discursive Structure of Humour in Stand-up Comedy Kenya: Discourse Topics and Stylistic Devices in Churchill's Performances
}

\author{
Mary Muthoni Githatu, Furaha Chai \\ Department of Literature, Languages and Linguistics, Egerton University, Nakuru, Kenya
}

Email address:

mgsonnie@yahoo.com (M. M. Githatu), optiondz@yahoo.com (F. Chai)

To cite this article:

Mary Muthoni Githatu, Furaha Chai. Discursive Structure of Humour in Stand-up Comedy Kenya: Discourse Topics and Stylistic Devices in Churchill's Performances. International Journal of Language and Linguistics. Vol. 3, No. 6, 2015, pp. 409-415.

doi: $10.11648 /$ j.ijl1.20150306.24

\begin{abstract}
Humour is a central component in stand-up comedy. The intent of a stand-up comedian is to amuse the audience and the audience laughter is a reaction to humour. This studysought to establish the discourse topics established by the standup comedian and the stylistic devices embedded in these topics to elicit laughter from the audience. To achieve this, the study focused on selected performances of Churchill, a comedian, in Churchill Live a Kenyan stand-up comedy. The study was guided by General Theory of Verbal Humour, which was useful in identifying the stylistic devices. Churchill routines from three episodes were transcribed for analysis. The results obtained indicate that social class, ethnicity, politics, religion and sports, are the most commonly discussed topics. The stylistic devices employed are contrast, songs, hyperbole, allusion, ridicule, ridicule and flashback.
\end{abstract}

Keywords: Discursive Structure, Humour, Discourse Topics, Stylistic Devices, Stand-Up Comedy, Kenya

\section{Introduction}

Stand-up comedy is a term for special genre of comedy in which the performer who is called stand-up comedian stands on stage and speaks directly to the audience. Stand-up comedy represents the most pervasive genre of literature across both time and space and having one role of eliciting laughter to the audience. Humour represents a central part in our everyday conversation and it is a general fact that all human beings naturally participate in humorous speech and behavior [1]. The stand-up comedian usually recites a fast paced succession of humorous stories, jokes called 'bit' and one of the many functions of the stand-up comedian apart from entertaining is dealing with and bringing forth, be it explicitly or implicitly, current issues and topics with which many people in society are concerned. Comedians often offer their insight to the audience about current issues and try to get the opinion of the audience. Some frequently seen topics are for instance, social class, ethnicity, politics, sports or other social differences, many of which are, on-liners which constitute what is typically called a monologue routine. To some extent, taboo or at least require being handled with care. Humour makes it easier to handle these topics without hurting the feelings of people.

In observing our behaviour in daily life, we surely realize that all of us regularly react with humour and laughter in most different situation. Humour and jokes surround and permeate our every business. They smooth our contact with other individuals and they play a special part in the relationship we maintain [2]. In reference [3] without laughter everyday living becomes drab and lifeless. Life would seem hardly human at all. Likewise a sense of humour is generally considered a person's most admirable trait. All human beings; educated and uneducated, rural and urban, young and old, and male and females are able to respond to humour i. e. to be amused to laugh or smile at something funny and thus are considered to have a sense of humour.

Churchill Liveis a Kenyan stand-up comedy that is aired on Nation Television (NTV). It was first aired in 2008 and since then it has become the favorite of many Kenyans. The comedy has become so popular that occasionally they travel to major towns in the country like Mombasa, Nakuru, Eldoret and Meru. This is to give Kenyans who cannot make it to the live recording in Nairobi an opportunity to watch it live. The comedy has been consistent in the recording a reflection that Kenyans have liked it and are ready to pay to be entertained. 
In the third season the comedy was re-branded to Churchill Show. The main host is Daniel Ndambuki who uses Churchill as the stage name. He performs alongside other comedians who are given limited time unlike Churchill.

The primary aim of this study is to establish the discourse topics brought forth byChurchill and the stylistic devices he employs to those topics to elicit laughter from the audience.

\section{Research Methodology}

The data for this study was drawn from Churchill Live stand-up comedy. The study specifically focused on the performances of Churchill who is the main host of the show. Purposive Sampling was used to arrive at the three episodes that were analyzed. The study had a total of thirty respondents from six secondary schools from Kajiado County, Kenya. Primary data was collected through interview schedule administered to the respondents to provide data for analysis. Secondary data consisted of the existing episodes of Churchill Live stand-up comedy which is recorded in the form of Digital Versatile/Video Disk (DVD). Churchill routines were transcribed from the DVD and presented in the analysis as illustrations. The researcher transcribed those parts of the episodes that had the required aspects as per the objectives of the study. The stand-up comedy is performed in the country's official languages; English and Kiswahili. However other codes; sheng and local languages are used though minimum. Therefore, English translations of the nonEnglish routines were presented. The analysis and interpretation of the data was guided by the General Theory of Verbal Humor. An interpretation of each episode was done taking into consideration the discourse topics and the stylistic devices. For ease of analysis, the transcribed data was organized as per the Framework of Analysis below.

Table 1. Framework of Analysis.

\begin{tabular}{|c|c|c|c|}
\hline Episode & Season & Discourse Topic & Stylistic Device \\
\hline 12 & 1 & $\begin{array}{l}\text { Ethnicity, Social } \\
\text { Class, Sports, } \\
\text { Politics }\end{array}$ & $\begin{array}{l}\text { Contrast, hyperbole, song, } \\
\text { gestures, body movement, } \\
\text { facial expression }\end{array}$ \\
\hline 15 & 1 & $\begin{array}{l}\text { Ethnicity, Sports, } \\
\text { Religion, }\end{array}$ & $\begin{array}{l}\text { Flashback, hyperbole, ridicule, } \\
\text { gestures, body movement, } \\
\text { facial expressions }\end{array}$ \\
\hline 9 & 1 & Ethnicity, Politics & $\begin{array}{l}\text { Flashback, hyperbole, } \\
\text { allusion, gestures, body } \\
\text { movement, facial expressions. }\end{array}$ \\
\hline
\end{tabular}

\section{The Results of the Analysis}

The findings of the study sought to meet the research objectives. The results point out to various emerging social topics which are brought out by the comedian in his routines. The comedian employed certain stylistic devices to elicit humour to the audience as he discussed the topics.

Discourse Topics (DT) and Stylistic Devices (SD)

DT refers to the various themes that are commented on by the comedian in his performance. The comedian who seems to be aware of the emerging topics discusses them on a light touch and also giving his insight to the audience as he tries to get their opinion. SD refers to distinct and unique language use and structure. It could be verbal or non-verbal. In order to achieve the humorous effects of the topics brought forth, the comedian employed verbal and non-verbal stylistic devices.

Extract 1

1. $\mathrm{CH}$ : They need to divide.

$2 . \quad$ I support it.

3. You can't mix Kibera, Langata na Karen

together. (and)

4. Aud: ((Laughter))

5. $\mathrm{CH}$ : They are different. $\mathrm{x} 2$

$6 . \quad$ Do you know I met eeeee ... my colleague.

7. She was an old lady. She is called Helon [Talks in Western English]

8. $\quad$ She told me.

9. Helon: Churchill I really do love your programme but you need to mind your language.

10. I don't like the way you talk about pets especially daisy.

11. CH: Daisy ni mbwa. (it's a dog)

12. Aud: ((Laughter))

13. Helon:

Because yesterday daisy was a little unwell.

15. She is under pradox.

16. CH: Pradox ni dawa ya mbwa. (It's a drug for drugs)

17. Now Kibera.

18. Mbwa ni mbwa. (A dog is a dog)

19. Aud: ((Laughter))

Hakuna mbwa ina jina ya kizungu ni Rodgers

20. CH: ama simba. Rodgers or Lion)

21. Aud: ((Laughter))

22. $\mathrm{CH}$ : Mbwa za Kibera zimezoea. (Dogs in Kibera are used to)

Zinaendaga mpaka kwa hoteli na butchery

23. jioni. (The dogs go to look for food at the butchery in the evening)

24. Mpaka kuna ile inafika. ( There are some dogs when they arrive at)

Mwenye butchery anaiambia... ( at the

25. butchery they are told to come the following day)

[Imitates the butcher and talks authoritatively]

26. Kesho! (tomorrow) [barks like a dog at the same time saying Yes]

27. Aud: ((Laughter))

28. They are different, totally different you know in Karen.

Which is still in the same constituency utapata

29. mtu akisema? (You will hear somebody saying )

30. I have a little migraine.

31. InKibera naumwa na kichwa. (In have a headache) 

32. Aud:
((Laughter))
33. CH: $\quad$ Na dawa yake( It's medicine)
34.
Enda pumzika kidogo itapona. (Go and rest for a while)
35.
In Karen someone says [talks in Western
36.
English]
37.
I have a running tummy.
Kibera ... Huyo anaendesha (that one is diarhhoeing)
38. Aud: ((laughter))

\subsection{Social Class (DT)}

In extract 1Churchill is supporting the division of three residential places: Kibera, Langata and Karen which are all in one constituency in Nairobi, the capital city. The three residential places are occupied by three different social classes. Kibera is an informal settlement for the poor, Langata the average income earners whereas Langata is for the middle class and above. Churchill uses a dog to show this social-economic difference. In Karen, dogs are treated like human beings and they are even given medication when taken ill. He talks of a dog named as Daisy and it is given pradox which is a drug when it was unwell. In Kibera dogs are named after wild animals and the owner has no resources to feed it. The dog has to hunt for itself food as in the case when it goes to a butcher and it's chased away. More so, he comments on some common illnesses among human beings. The illnesses have different names depending on where the ailing person resides. For the residents of Karen he uses sophisticated words when referring to the illnesses. Terms such as migraine and a running stomach are used. In Kibera, the same illnesses are referred to as headache and diarhhoering respectively. The latter being a taboo word. These residents from Kibera will not be treated when having a headache perhaps for lack of money to buy the drug. One is told to rest for a while as the treatment. It's ironic compared to the dog from Karen which is treated when taken ill.

\subsection{Contrast (SD)}

This is the artistic of placing two events or personalities to reveal their dualities or characteristics by means of contrast or juxtaposition [4]. From extract 1 Churchill has contrasted the haves and the have-nots in the society. He uses a dog to show this social inequality. A dog owned by the rich is given names like those given to human beings i. e Daisy. The dog is treated when taken ill since the owner can afford to pay for its treatment. A dog from a peasant family has to hunt for its food which is a basic need for it. It is normally chased away when it barks for food because the owner hardly has enough to feed his family. From the same extract Churchill uses sophisticated terms when referring to common illnesses. In Karen, the rich, pain in the head is referred as migraine while in Kibera, the peasants refer to it as headache and one is not treated. Another illness is a running stomach which is a term used by residents of Karen while in Kibera the same illness is referred to as diarhhoea which is a taboo word. The irony that comes out from this contrast is that a dog from the rich family is treated when unwell while a human being from a peasant family is unwell goes untreated for lack of resources.

\subsection{Ethnicity (DT)}

Some ethnic peculiarities, tendencies and characteristics are highlighted amongst major communities in Kenya. Fought [5] defines ethnic groups as human groups that entertain a subject belief in their common descent because of similarities of physical type or of customs or both, because of memories of colonialization and migration... it does not matter whether or not an objective blood relations exists. The comedian draws from cultural beliefs which they may share with the audience in order to humorously stereotype the target in their joke [6]

Extract 2

1. $\mathrm{CH}$ : Wabaluhya $\mathrm{x} 2$

2. Bushiere $\mathrm{x} 2$

3. DJ do you have that song?[A song is played]

4. There is a way they cry.

5. Aud: ((Laughter))

6. $\mathrm{CH}$ : Have you noticed how Luhyas cry?

Wanacryna gear [sings along to a Luhya song as

7. he demonstrates with an imaginary gear] (They cry in gears)

8. $\quad$ Eeiiiii iiii.

9. Mimi nangoja gear. ( I am waiting for the gear)

10. ya nne na ya tano. (the second the third the fourth and the fifth gear)

[A Luhya song is played]

Muyanzi waanje muyanzi wanje vane

11. Mundu mulosi iwe, waimarira van vanje Muyanzi waanje muyanzi wanje vane

Mundu mulosi iwe, waimarira ridalaa

12. Ebu Imbeni niskie(Sing so that I can hear you know the song)

13. Aud: [audience joins in the song]

14. CH: Nani anataka kutuma salamu? x2 ( Who wants to send greetings?)

Hizo salamu mnatoanga wapi?[removes a paper

15. from his pocket] (Where do you get those greetings from?)

16. Umebeba tu karatasi. (You have only carried a paper )

Ningependa kutuma salamu kwa Wandaka,

17. Stephen wandaka, na Wandaka woooote. (I would like to send my greetings to Stephen Wandaka and all the Wandakas)

18. Aud: ((laughter))

19. $\mathrm{CH}$ : A big hand to all the Luhyas in the house.

260Aud: ((Laughter and applause)) Bushiere is a Luhya word used in greetings

Extract 2 above Churchill is commenting about the Luhya community. He starts his routine by greeting the audience with the Luhya language Bushiere. He then comments on how the Luhyas mourn with passion. They accelerate their 
cry just like a car accelerates by changing gears. He later asks for a Luhya song which he sings together with the audience. This gives him an opportunity to tease Luhyas for sending greetings over the radio. Most radio stations have call-in programmes where listeners call to send greetings or they buy greeting cards which are read by the broadcaster. Luhyas are fond of listening to the radio and sending greetings.

Extract 3

1. $\mathrm{CH}$ : I have stopped going to Mombasa.

2. The reason why I don't go to Mombasa for holiday.

Nairobi yote iko huko. (Everyone who resides in Nairobi goes to Mombasa)

4. Ukipiga kona unakutana na akina Njoroge. (You negotiate a corner you meet Njoroge)

[Imitates a kikuyu speaker] Riu ri ata wewe uko

5. hapa?

(You are also here in Mombasa)

6. Uko hotel gani? (which hotel are you putting up in?)

7. Hii iko hapa ya beach. (This one next to the beach)

8. Ata mimi niko hii ya beach. (Am also in this one 8. next to the beach)

9. Hivo umeogelea? (So you are swimming) Mi niko biashara. (No am here on business)

11. Aud: ((laughter))

Na umekuja holiday. (And you have come for

12. $\mathrm{CH}$ : holiday)

Riu riis a kikuyu word which means now ${ }^{1}$

From extract 3 Churchill gives his reason why he no longer goes to Mombasa for holiday. Mombasa is a coastal town that attracts domestic and international tourists. It is popular for holiday makers especially those from upcountry who go swimming at the public beaches. He says that all Nairobi residents usually go to Mombasa and while there he bumps into Njoroge, who is a kikuyu. He is happy to meet Njoroge and he asks him which hotel he is putting up in. Njoroge informs him that his hotel is located just next to the beach. This excites Churchill as he is also in the same location. Churchill teases him that he must be swimming a lot. To his surprise Njoroge tell Churchill that he is there for business. Churchill here is poking Kikuyus enterprising nature. They are known to be very aggressive in business that even when one is on holiday a Kikuyu will still engage in business.

\subsection{Songs (SD)}

Songs are about the people's condition of life, about their political, social and economic activities. They not only entertain, but have important messages to communicate to mould the publicopinion[7]. In the live recording of the stand-up comedy there is a live band that keeps entertaining the audience and also plays songs as requested by the comedian. The song below from extract 2 helps Churchill to

1 Luhya and Kikuyu are ethnic groups in Kenya.

engage the audience. It gives him the forum to highlight some Luhya stereotypes like listening to radio and sending greetings. The audience who are familiar with the song are happy as they stand up to dance shaking their shoulders an idiom for Luhyas dance. In almost all episodes the last section has an artist who is gets an opportunity to market his/her latest song or share his/her experience as a performing artist. At the same time the audience gets entertained and dances to break the monotony of sitting for long.

[A Luhya song is played]

Muyanzi waanje muyanzi wanje vane my dear, my dear

Mundu mulosi iwe, waimarira van vanje you witch man, you have finished my

11. $\mathrm{CH}$ : children

Muyanzi waanje muyanzi wanje vane my dear, my dear

Mundu mulosi iwe, waimarira ridalaa you witch man you have finished my children

\subsection{Hyperbole (SD)}

In reference [8] hyperbole is a figure of speech which contains an exaggeration for emphasis. It mainly serves to exaggerate familiar situations, to make the audience appreciate joke telling. From extract 3 Churchill is exaggerating that he no longer goes to Mombasa because all the residents of Nairobi go there. This is an exaggeration because it is not everyone in Nairobi probably it is only a small fraction of them that goes to Mombasa on holiday. He also exaggerates that a kikuyu will go for holiday, puts up in a hotel next to the beach so that he can tap business opportunities from the holiday makers at the beach. He is only emphasizing that Kikuyus are very aggressive in business and mean to themselves that they cannot take time off business to relax.

\subsection{Politics (DT)}

The comedian has addressed politics in the country. Greed, selfishness and poor governance among the politicians is highlighted.

Extract 4

\section{1. $\mathrm{CH}$ :}

2. Aud:

3. Najib:

4. Aud:

5. $\mathrm{CH}$ :

6. $\mathrm{CH}$ :

7. Aud:
Sasa tax unakatwa lini? ((When will you start paying tax?))

[shouting yes and some laughing]

Niko tayari ata leo ukianza niko tayari. ((I am ready even if it's effected today))

[jeer]

Uko tayari kukatwa? ((Are you ready to pay tax))

Pigieni mheshimiwa makofi. ((Give an applaud to the honourable member))

[Some audience clap and others continue jeering]

These are the breaking news. 
9.

10.

$$
\text { 11. Aud: ((Laughter)) }
$$

Elected leaders in Kenya do not pay taxes. This has always disgruntled Kenyans since they are handsomely paid and in return they do very little to help the electorate once they get in office. Churching is interviewing a legislator, Najib in extract 4 . He asks him when he will start paying tax. The legislator says anytime he is ready to pay. The audience jeer at him as it is obvious that the elected leaders do not pay tax something that they have blatantly refused.

\section{Extract 5}

1. $\mathrm{CH}$ : One last thing is about politicians.

2. One thing I wish wangepelekwa probation. (They

are put on probation)

3. You know so that we vote.

4. Wako probation. (They)

5. President Kibaki then Raila then Kalonzo.

6. Na judge Ian amesema pathetic. (And...has said)

7. Can you imagine President Kibaki asking for your votes. $^{2}$

In Extract 5 Churchill talks about three profile politicians in the country. These are Kibaki, Raila and Kalonzo (see footnote 4). Churchill recommends that they should be put on probation so that the citizenry can decide whether they should continue being in office. Many politicians forget the electorate that voted them in office. They only remember them when there are elections. If put on probation, the politicians will be on check so as to deliver their manifesto to the citizenry.

\subsection{Allusion (SD)}

Allusion involves extra linguistic knowledge that allows the joke tellers to create solidarity with their audience. In [9] allusion is an indirect or passing reference to some event, person, place or artistic work, the nature and relevance of which is not explained by the writer but relies on the reader's familiarity with what is thus mentioned. Before the comedian makes an illusion, he presupposes that the listener is familiar with the ideas being alluded to and that will make the listener think of the same concept that the speaker has in mind. In extract 5 Churchill alludes to three politicians in the country: Kibaki, the president; Raila, Prime Minister and Kalonzo, vice-president. The three were in a power sharing government (2008-2013). They are public figures who are known by all Kenyans. By suggesting they be put on probation and judge Ian says pathetic, he is alluding to a reality show Tusker Project Fame. The show trains singers and the winner goes with a jack pot. During the period the contestants who sing badly are put on probation by the judges and for them to be back in the academy the contestant requests the viewers to vote

2 Najib was a member of parliament between 2008-2013.

Kibaki, Raila and Kalonzo governed Kenya in a power sharing government following a disputed election in 2007. for them so as not to be evicted. The contestant who gets the least votes is evicted. Churchill says that similar action should be done to the politicians to send home nonperforming politicians. The audience is really amused when Churchill imitates the speech mannerisms of the three politicians.

\subsection{Religion (DT)}

Kenya has a diversity of religions. The comedian being a Christian makes references to certain anti-Christian practices in the modern society.

Extract 6

1. $\mathrm{CH}$ : The Luos $\mathrm{x} 2$ are so proud even in prayers.

2. Aud: ((laughter))

3. $\mathrm{CH}$ : Lord $\mathrm{x} 2$ yees yees oooh.

4. What is so big to you?

5. You have given me a Range Rover, a house...

6. Aud: ((Laughter))

7. $\mathrm{CH}$ : What is a BMW X6 for you?

8. Aud: ((laughter))

9. $\mathrm{CH}$ : Throw it as a bonus.

10. Aud: ((Laughter))

11. CH: Then throw it somewhere.

12. What can't you do?

13. Aud: ((Laughter))

14. CH: Yes you can, if you did for Obama.

15. You can do it for me.

16. Aud: ((laughter))

Christians are taught to pray to God to provide their needs. Churchill refers to a Luo Christian who is so proud to God and is not patient to wait for the prayers to be answered. Luos are stereotyped as proud and living a sophisticated lifestyle. The Luo is asking God to give him a BMW X6 model of a car which is very expensive. He is impatient to wait and seems to be questioning God's ability because the same God made Obama a president. This is a comment on Christians who are impatient with God contrary to the Christians teachings which teach Christians to be patient.

\subsection{Ridicule (SD)}

This refers to a form of attack against a person, thing or idea. It is designed to cause laughter and humiliation and takes a number of forms: deriding which involves attacking someone with scornful tone, mocking, which is to imitate another's appearance or action; and taunting, which is to remind someone of some annoying fact [10]. Extract 6 Churchill is ridiculing Luos for their sophisticated lifestyle. The punchline of the joke is that the Luo is demanding a very expensive model of a car. In extract 1 he also ridicules the Luhyas for sending greetings.

\subsection{Sports (DT)}

Soccer and athletics are the common sports that Kenyans engage in. The sports commented on are athletics and soccer. Extract 7

1. $\mathrm{CH}$ : We need to give it up for International Athletics 


\author{
World Champion IAAF. \\ $2 . \quad$ What's his name? \\ 3. Aud: [Audience shout] Rudisha. \\ 4. CH: What's his first name? \\ 5. Aud: David Rudisha. \\ 6. $\mathrm{CH}$ : A big hand to our brother David Rudisha \\ 7. Aud: ((Applaud)) \\ Extract 8
}

1. (Congratulations to Tanzania on winning CECAFA)

I'm telling you they are talking about that tournament.

3. [Talks in Kiswahili Coast accent] Timu twaenda

worldicup. (Our team is going to the world cup)

4. Tulifunga Ivory Coast. (We beat)

Ivory Coast timu kubwa ya kina Didier Drogba

5. teule. (Ivory coast is a big team with international players like Didier Drogba)

6. Aud: ((laughter))

Tanzania tuliwafunga finali magoli takribu, takriban, madude. Tuliwanyeshea magoli

7. $\mathrm{CH}$ : takriban moja.

(Tanzania we beat them several goals. . we beat them one goal)

8. Aud: ((Laughter))

9. $\mathrm{CH}$ : The other thing Arsenal na Man U.

10. Man U eee Man U.

11. Aud: Aaaa...

12. $\mathrm{CH}$ : Kati ya Man U na Arsenali nani kali? (Between Man u and Arsenal which one is tough?)

13. Aud: [some shout Man U others shout Arsenal]

14. CH: Appreciate Man U walishinda. (Appreciate Man

$\mathrm{U}$ won the tournament)

In extract 7 Churchill is congratulating a Kenyan athlete David Rudisha for having won Internatinal Athletics Amateur Federation (IAAF) which is an athletic competition. Rudisha had made Kenya proud for winning the competition. The audience too is proud of him as they are smiling and shout out his full name. Also in extract 8 he congratulates Tanzania, an East African country, for winning Confederation of East and Central African football Association (CECAFA). Tanzania had defeated the defending champion Ivory Coast, which plays at world cup. This made Tanzanians to be so proud of their team that it was the topic of the day. In the same extract he discusses two English soccer teams; Manchester United (Man U) and Arsenal. Once more he congratulates Man $U$ for having beaten Arsenal in a just concluded fixture. The audience who support Man U are very excited while those who support Arsenal are jeering at the Man $U$ fans in the audience.

\subsection{Flashback (SD)}

This is when the chronological structure of narration is broken to introduce past events in the present circumstances [4]. In extract 7 and 8, Churchill uses flashbacks to congratulate the winners in the sports he discusses. Extract 7, he congratulates David Rudisha having won IAAF in a recently concluded competition. He had beaten a Jamaican, Usain Bolt who was the defending champion. Extract 8, he again uses flashbacks to congratulate two soccer teams; Tanzania's national team and Man U an English soccer team.

\section{Conclusion}

From the analysis, it is evident that the stand-up comedian addresses emerging social issues and has effectively employed stylistic devices to humorously discuss these topics. Stand-up comedy is a mirror in which the society is reflected. The dominant topic being ethnicity where the various ethnic groups in Kenya are stereotyped; especially the dominant ones like Kikuyus and Luhyas. The comedian uses a variety of codes to amuse his audience. Occasionally he uses words or expressions from the ethnic group he is teasing. This creates solidarity with the group being teased. Other topics discussed are social class, politics religion and sports. Being the main host of the show, Churchill is given more time on stage hence addresses a variety of emerging social topics.

To bring out the hilarious effect of the topics being discussed, the comedian employs stylistic devices. These styles have made it easy for the comedian to discuss topics that would have otherwise offended the audience or the guests invited. The verbal stylistic devices are: contrast, songs, hyperbole, allusion, and ridicule. To enhance the humour the comedian too employed non-verbal stylistics such as gestures, facial expressions, body movementand audio-visual clips.

\section{Appendix}

Transcription conventions

1. Tanzania hongera kwa kushida CECAFA Bold and italics routines in Kiswahili

2. Bushiere: Italics show expressions in a local language

3. (Tanzania congratulations on winning CECAFA) Single brackets routine translated to English

4. Do you know I met eee... my colleague ... ellipsis shows pauses of more than a second

5. CH: Churchill

6. Aud: Audience.

\section{References}

[1] Schwarz, J. (2010) Linguistic Analysis of Verbal Humour. PHD Dissertation: Sarland.

[2] Rutter, J. (1997) Stand up as interaction: Performance and audience in comedy venues. Sarland.

[3] Grunner, C. (1978) Understanding laughter. Chicago: NelsonHall.

[4] Barnet, et al (1993) An Introduction to Literature, Fiction, Poetry, and Drama $10^{\text {th }}$ edn. Newyork: Harper college publishers. 
[5] Fought, C. (2006) Language and ethnicity: Key topics in Sociolinguistics. Newyork: CUP.

[6] Filani, I. Discourse Types in stand-up comedy performances: an example of Nigerian Stand-uo Comedy. Published.

[7] Akivaga, S. K. and Odaga, B. A. ((1984)) Oral Literature. Nairobi, Kenya: East African Educational Publishers.
[8] Cuddon, J. A (1977) A dictionary of Literary Terms. London: Deutsch.

[9] Baldick, C. (1990) The Concise Dictionary of Literary Terms. Oxford: OUP.

[10] Berger, A. A (1993) The Anatomy of Humour. New Brunwick: Transaction Publishers. 